\title{
Home Industry Soybean Milk Marketing Assistance
}

\author{
Khoirul Ifa \\ Department of Accounting, STIE Widya Gama Lumajang \\ khoirul.ifa@gmail.com
}

\begin{tabular}{lll}
\hline Submission : & Review : & Publication : \\
$4^{\text {st }}$ January 2020 & $13^{\text {th }}$ January 2020 & $28^{\text {th }}$ February 2020 \\
\hline
\end{tabular}

\begin{abstract}
Abstrak
This activity aims to assist product packaging innovation, innovate flavors and product variances, and provide marketing assistance. The approach offered for solving partner problems consists of surveys, interviews, practice, monitoring and evaluation. The product innovation and marketing assistance that has been proposed has succeeded in making soy milk packaging more attractive and varied, while the innovation in the taste of soy milk also makes the product taste different from before, marketing assistance makes partners more competitive and can expand the market This activity is fully supported by the soy milk business group, because it succeeded in providing new ideas in terms of providing packaging design, flavor variance innovation and product marketing.
\end{abstract}

\section{Keywords : Home Industry, Marketing, Innovation}

\section{INTRODUCTION}

Soybeans are a type of legume that are widely available in East Asia. They are classified as oilseeds. Soybeans are considered a complete protein due to the presence of large amounts of essential amino acids. The benefits of soy are found in countries such as China and Japan, where people are less likely to develop heart disease, osteoporosis, breast cancer and prostate gland. (Kompas.com)

Soybeans can be processed into various foods such as tofu, tempeh, soy sauce, soy flour, snacks and soy milk, various preparations from soy, apart from tofu, which most people enjoy doing, namely soy milk. Soy milk is a good source of protein as a substitute for cow's milk. This soy milk is lactose-free which is often used by consumers who are not compatible with lactose or are allergic to cow's milk (Heinnermen, 2003).

Soy milk is believed to contain a lot of vegetable protein which is good for the growth of bones and teeth. According to the Iowa State University Database on the Isoflavone Content of Food, soybean juice (soymilk) has a sizeable amount of total isoflavones of 9.56 $\mathrm{mg} / 100 \mathrm{~g}$ which reduces atherogenesis and decreases bone reabsorption, reduces the prevalence of breast and prostate cancer, and reduces risk of atherosclerosis, neurodegeneration and osteoporosis (Otieno dan Shah, 2006). Of these various properties, soy milk is increasingly favored by the public, apart from its delicious taste, soy milk is also rich in benefits. This is certainly an opportunity to run a business in the processing of soy milk.

In Jember Regency, there is a small-scale soy milk entrepreneur in Karang Duren village, whose owner is Mustafidatus Zuhro. The business was started in 2011, in a day, business owners can produce 200-300 packs of soy milk which are marketed in traditional markets and nearby stalls. When she started this business, she was only assisted by her 
husband, now this business is quite developed by employing 4 employees. The wage system is daily, the daily wage of employees is around Rp. 10,000-15,000. However, this business did not escape from various problems, in 2015 when the price of soybeans soared, Fida did not produce soy milk because the raw material in this case soybeans was quite expensive so that its sales turnover decreased.

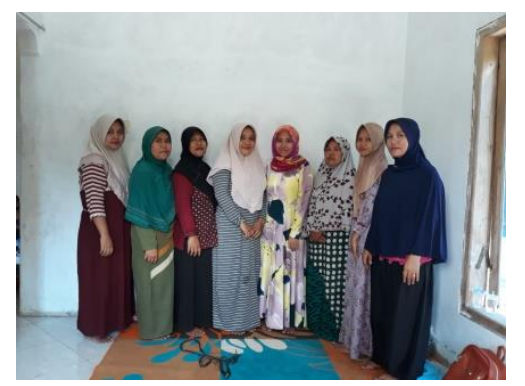

Figure 1. Initial Survey of Soy Milk Business in Karang Duren Village

The raw material for making soy milk is soy. The raw materials come from soybean retailers in Karangduren village, Balung district. The price of raw materials is IDR $8,000 / \mathrm{kg}$. The process of producing soy milk is carried out every day, starting from 03.00 in the morning to 05.00 in the morning it is ready to be marketed. In a day the production can reach $10 \mathrm{~kg}$. the process of making soy milk using a grinding machine with a capacity of $1 \mathrm{~kg}$.

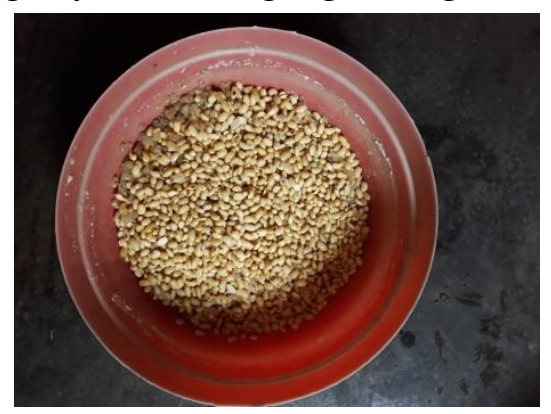

Figure 2. Overview of Raw Materials (Soybean)

The first step in making soy milk is soaking soybeans for about 5 hours, after soaking the next process is milling and then squeezing the soybean pulp is extracted using a manual method using a cloth, before squeezing the soybean pulp is added water, with a ratio of 9 liters of water in $1 \mathrm{~kg}$ of soybeans. . The next process is boiling, where sugar is added in a ratio of $1 \mathrm{~kg}$ of soybeans to $1 \mathrm{~kg}$ of sugar. The soy milk that is still warm is then poured into plastic packaging (small plastic ice cubes) for sale. The following is the process of making soy milk:

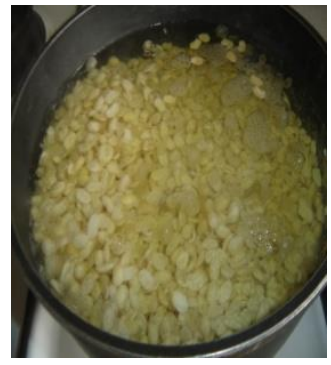

Step 1 Soybean Soaked 5 hours

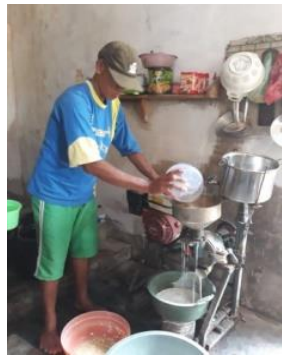

Step 2 Milling Process

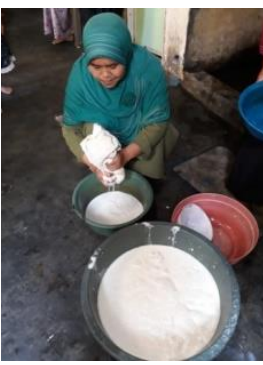

Step 3 Squeeze the 


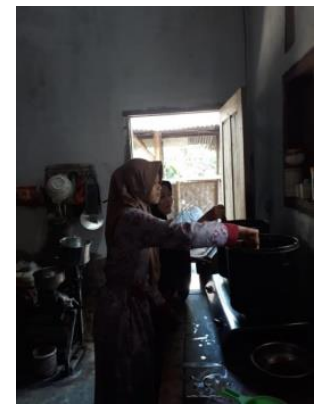

Step 4 Cook milk

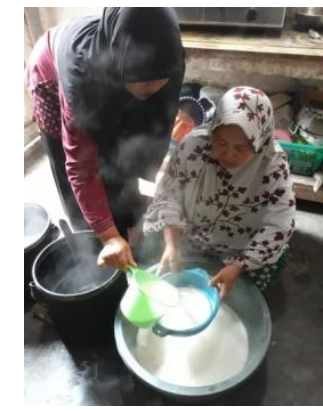

Step 5

Cooked milk is filtered again

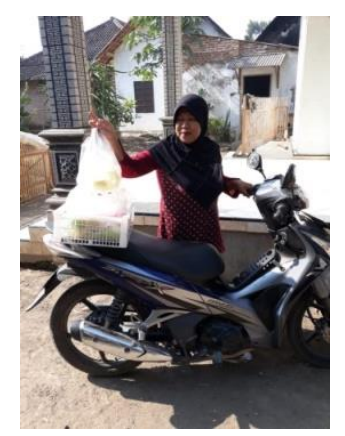

Step 7

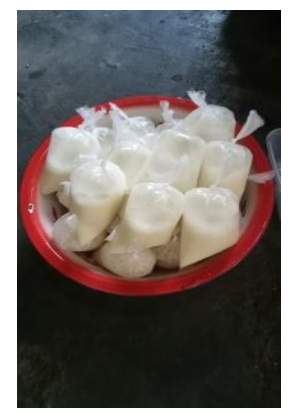

Step 6 Milk packaging process

Ready to market milk

Figure 3. The process of making soy milk

The soy milk production process is still classified as traditional, the methods used are still traditional, even the production process is considered less sterile because the milking process still uses used cloth. Marketing of soy milk products is limited, namely in traditional markets and nearby stalls with a trustworthy system. Consumers of soy milk are mobile vegetable traders, children and adults. This soy milk business in business management still uses a household pattern, so that there is no separation between household income and expenditure with income and expenditure for the business.

The milling process of soy milk uses a grinding machine with a capacity of $1 \mathrm{~kg}$ so that the milling process must be repeated and cannot produce on a large scale, besides that the grinding machine has not separated the soybean dregs from soybean juice so the squeezing process is still using manual method, this method is less sterile because it uses hand and used cloth.
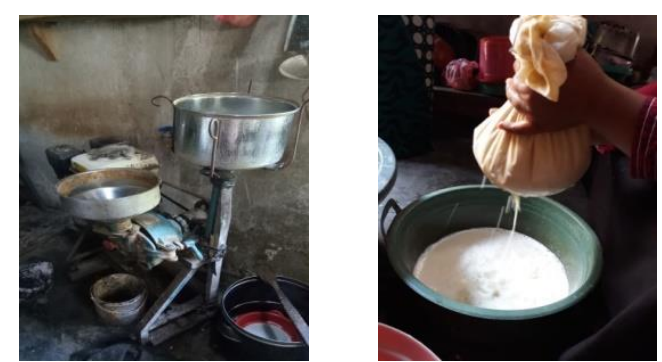

Figure 4. Manual soy milk grinding machine in Karangduren village 
Soy milk packaging still uses small plastic ice cubes so that it is less attractive to customers, plastic packaging is also less sterile and causes the milk to spoil quickly (not durable). Soy milk has also not been given a name / brand so that it is less well known by the public. Soy milk does not use any flavor so there is no appeal to customers, this makes the market easily saturated. There is only one kind of product, so there are no other processed products besides soy milk. Soybean dregs are only used for chicken feed, so there is no added value from soybean dregs.

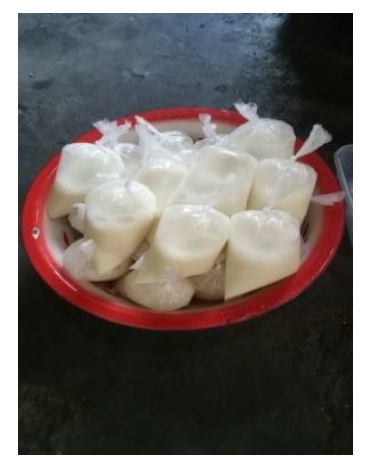

Figure 5. Soy milk in Karangduren village, Jember district

Another obstacle in this business is marketing constraints, marketing is limited to local areas, namely Balung, Umbulsari, and surrounding districts. Marketing is still traditional in nature, namely word of mouth. The marketing strategy has not been implemented, making it difficult for this business to develop. Besides, the resulting product is less attractive in terms of packaging appearance and taste. There is no promotional media, especially online promotion. Limited knowledge of computers and the internet is an obstacle in marketing products online.

Business management is carried out with a household management pattern, so that it does not separate household income and expenses from the business, this will have an impact on business progress. In terms of income and expenses that have never been recorded properly, whether it is daily, weekly, monthly or even annual income or expenses, so it is difficult to analyze the income statement, even though with the profit and loss statement, the business owner will get information about the profit and loss obtained, making it easier for owners to make decisions because there is already concrete evidence of financial statements. In addition, human resource management is not yet organized, so that every worker has the same role in the business.

From the above problems, the proposer team and partners have discussed and agreed to make a priority scale for the existing problems to be resolved, along with the description: The soybean milling process is less efficient, because the machine has a capacity of only $1 \mathrm{~kg}$ and cannot separate soybean pulp from its juice, Not optimal product innovation both packaging innovation, taste and product variance, The marketing aspect has not been optimal so that product marketing is limited to local areas, The business management system is not yet optimal because it still uses the household management pattern in terms of division of labor and the bookkeeping system is not yet optimal whether it is daily, weekly, monthly and yearly.

\section{IMPLEMENTATION METHODS}

The approach method offered to solve partner problems consists of the following steps: (1) Survey, Survey activities will be carried out to see the partner's business conditions, (2) Interview, The interview aims to gather information related to partner problems and at the 
same time find solutions, (3) Packaging innovation, The packaging innovation was assisted by the lecturer by designing more attractive and unique packaging, (4) Practice taste innovation,Practice making flavors other than the original ones, namely strawberry, melon and durian flavors, (5) Monitoring and evaluation, Monitoring and evaluation activities will be carried out periodically until partners can produce innovative products so that the targets and outputs of this program can be achieved.

\section{RESULTS AND DISCUSSION}

Initial preparation before conducting interviews with soy milk business actors in Karangduren village, Jember Regency is a survey, survey activities are carried out with the aim of seeing the initial conditions of the soy milk business, this activity also aims to prepare community service programs, and aims to collect data and information related to business .

The survey activity was carried out on August 19, 2019, the survey findings revealed that this business was underdeveloped in addition to the lack of packaging product innovation, flavor innovation, and marketing constraints. The survey activity also resulted in a series of community service program arrangements which were subsequently discussed by partners and community service program implementers. The following is the result of a documented survey of the soy milk business group in Karangduren village, Balung district, Jember district.

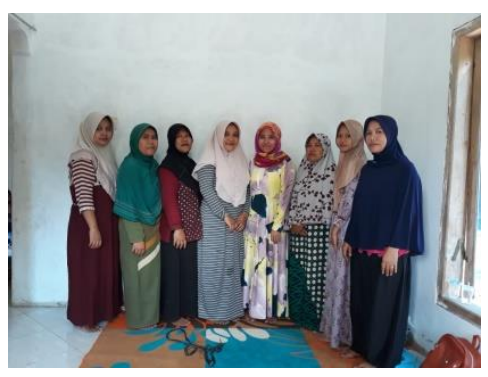

\section{Figure 6. Soy Milk Home Industry Survey Activity in Karangduren Village, Balung District, Jember Regency}

The second step in implementing a community service program is the interview activity. The interview is needed to dig up information related to the soy milk business, information that is extracted is in the form of business identity, capital and turnover, number of workers, selling price, materials used, equipment used, marketing area, raw materials, manufacturing processes and production results. .

Interview activities were carried out on August 20, 2019, the results of interviews showed the soy milk business had many problems, in terms of packaging it was still simple, namely using small and thin plastic, packaging labels were still missing. Besides that, the taste variance is only 1 kind, namely the original taste, while the marketing of soy milk is only in stalls and traditional markets. The production process tends to take a long time because it only uses a simple milling machine, this of course makes it difficult for this business to develop. Soy milk is much loved by the local community because of its good taste, the price of soy milk is also relatively cheap. Assistance for shrimp paste cracker business actors is very necessary so that business actors are more independent.

This soy milk business was founded in 2000, the owner of this business is named Ibu Mustafidatus Zuhro. This business is a food business that is run by a family and relatives consisting of mother, father and siblings. The soy milk business capital is only Rp. 500,000 then it grows along with the large number of orders, the most orders are usually when there 
are celebrations such as weddings, buffet activities, posyandu, etc., daily consumers of soy milk are mobile vegetable traders, traditional markets and nearby stalls. . The business turnover is around Rp. 200,000 per day, but if the number of orders increases the turnover of this business increases, reaching Rp. 300,000-500,000 per day. The number of workers is only 3 people consisting of relatives. This business base is the home industry. The selling price per unit of soy milk is Rp. 1,000 because they only pack it in small plastic which is then deposited at food stalls, vegetable traders. The ingredients used include soybeans, sugar, salt, food coloring. The equipment used is a fireplace, stove. The marketing area is the local area of Jember, namely the area around the Balung sub-district, which consists of the closest stalls, vegetable traders, and traders in the market. The raw material for making soy milk is soy which can be purchased at the nearest store. One kilogram of good quality soybeans costs Rp. 8,000. Soybean raw materials can be purchased at crafting shops and markets, while other complementary materials are also often found in planning shops and nearby markets, so the raw materials are relatively easy to obtain.

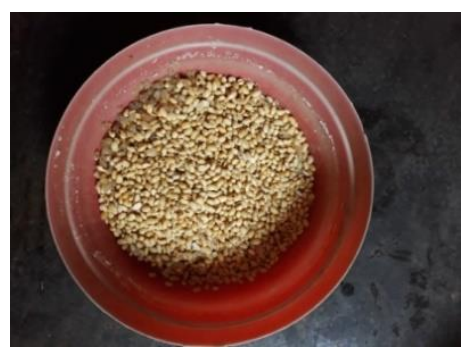

Figure 7. Soy Milk Raw Materials

The practice of product innovation was carried out on August 21, 2019, a group of entrepreneurs were enthusiastic in providing directions from the community service implementation team, lecturers assisted business groups in innovating product taste. In terms of practice, they did not experience difficulties because they already had provisions in making soy milk.

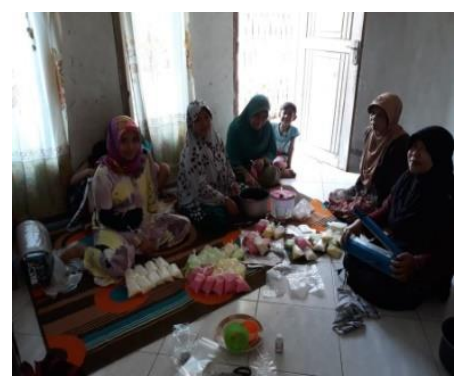

Figure 8. Innovation Practices

The results of the soy milk entrepreneur's product innovation are very interesting, both in terms of packaging and in terms of taste, product innovation produces 3 flavors, namely strawberry, melon and durian.

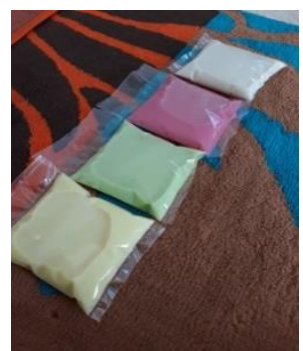

Figure 9. Product Innovation Practice Activities 
After carrying out innovative practices, the next mentoring activity is marketing assistance, marketing assistance is carried out in design shops, fitness centers and through social media such as Facebook and Instagram.
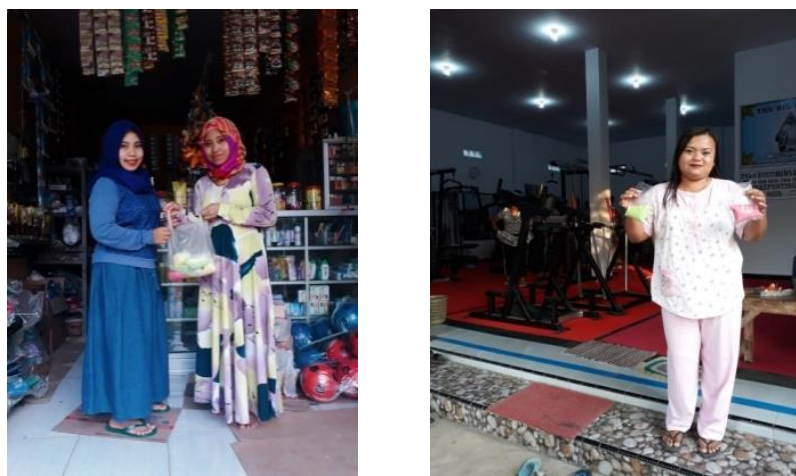

Figure 10. Marketing assistance

The equipment assistance to partners aims to make the soy milk production process run well and produce more packaging to support their business activities. Equipment assistance is also carried out with the aim of making partners more independent in producing higher quality products.

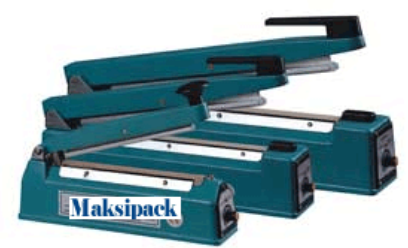

Figure 11. Delivery of Equipment Assistance

\section{CONCLUSION}

The community service program runs well and smoothly, the product innovation assistance and marketing that have been proposed have succeeded in making soy milk packaging more attractive and varied, while the innovation of soy milk taste also makes the product taste different from before, marketing assistance makes partners more competitive and can expand the market This activity has the full support of the soy milk business group, as it has succeeded in providing new ideas in terms of providing packaging design, flavor variance innovation and product marketing.

Based on the activities that have been carried out, several suggestions can be made as follows:

1. The existence of similar activities should always be held periodically so as to improve the skills and independence of MSMEs.

2. The minimal operational costs for activities make innovation and marketing limited.

3. In addition to product packaging innovation, there are still many other community service activities that need to be developed such as management training, proper and correct accounting recording training, and so on. 


\section{REFERENCES}

Heinnermen, J. (2003). Khasiat Kedelai Bagi Kesehatan Anda. Prestasi Pustaka. Jakarta

Otieno, D.O., Ashton, J.F, Shah, N.P. (2006). Evaluation of enzymic potential for biotransformation of isoflavone phytoestrogen in soymilk by Bifidobacterium animalis, Lactobacillus acidophilus and Lactobacillus casei. Food Research International 39 (2006) Elsevier. 394-407

Kompas.com .8 Manfaat Kedelai Bagi Kesehatan. https://lifestyle.kompas.com/. Diakses 15 Agustus 2018 